\title{
ВИКОРИСТАННЯ ВІДЕОМАТЕРІАЛІВ ЯК ЗАСОБУ ФОРМУВАННЯ ІНШОМОВНОЇ КОМПЕТЕНТНОСТІ МАЙБУТНІХ ФАХІВЦІВ ІЗ СТОМАТОЛОГІї
}

\author{
O. Bohomolets National Medical University \\ USING VIDEO MATERIALS AS A MEANS OF FUTURE DENTISTS' \\ FOREIGN LANGUAGE COMPETENCE FORMATION
}

\begin{abstract}
Анотація. У контексті реформування медичної освіти, зокрема у галузі стоматології, великого значення набуває необхідність формування іншомовної компетентності, яка сприятиме ефективному здійсненню лікарської і наукової діяльності. У статті розглядаються переваги використання відеоматеріалів як одного із засобів формування іншомовної компетентності майбутніх стоматологів на практичних заняттях з іноземної мови у медичних закладах вищої освіти. Зважаючи на факт, що відеоматеріали $\epsilon$ основним джерелом автентичної іноземної мови, відповідно, їх використання на заняттях значно покращить процес формування іншомовної компетентності майбутніх фахівців із стоматології. Визначено етапи презентації відеоматеріалів на практичному занятті, а саме: «підготовчий етап», «етап перегляду», «робота з відеоматеріалом» та «використання відеоматеріалу в комунікативній ситуації». Також у статті зазначені необхідні умови для покращення процесу формування іншомовної компетентності майбутніх фахівців із стоматології шляхом використання відеоматеріалів. Обгрунтовано доцільність використання вправ та завдань на кожному етапі презентації відеоматеріалу.

Запропонована організація демонстрації відеоматеріалів сприятиме підвищенню якості процесу формування іншомовної компетентності майбутніх фахівців із стоматології на заняттях з іноземної мови шляхом використання розроблених завдань для кожного етапу перегляду відеоматеріалу та підвищення мотивації до навчання через професійний контент.
\end{abstract}

Ключові слова: відеоматеріали; іншомовна компетентність; компетентнісний підхід; комунікативна компетентність; мотивація.

Abstract. In terms of reforming medical education, particularly in the field of dentistry, it is very important to develop foreign language competence that facilitates the effective implementation of medical and scientific activities. The article deals with the advantages of using video materials as a means of future dentists' foreign language competence formation during foreign language lessons in medical universities. Taking into account the fact that video materials are the main source of authentic foreign language, their application in the classroom significantly improves the process of future dentists' foreign language competence formation. The article defines the stages of applying video materials during a foreign language lesson, namely: "preparation stage”, "viewing stage”, "stage of working with video material" and "using video material in a communicative situation". The article also considers the necessary conditions for facilitating the process of future dentists' foreign language competence formation through the application of video materials. The expediency of applying different tasks and activities at each stage of video presentation is substantiated.

Presented way of video demonstration will improve the quality of future dentists' foreign language competence formation process by using the developed tasks for each stage of viewing the video material and enhancing the motivation to learn through using professional video content.

Key words: video materials; foreign language competence; competency-based approach; communicative competence; motivation.

Вступ. Наразі триває процес реформування фахової медичної освіти на основі компетентнісного підходу, визначальним фактором у реалізації якого $\epsilon$ зорієнтованість на розвиток системного комплексу умінь, смислових орієнтацій, адаптаційних можливостей, досвіду і способів трансформаційної діяльності з отриманням конкретного продукту [5]. Як зазначає К. Рудницька, компетентнісний підхід передбачає не лише трансляцію знань, умінь і на- вичок від викладача до студента, а формування у майбутніх фахівців професійної компетентності [7]. Реалізація такого підходу спрямована на застосування інтерактивних методів навчання майбутніх фахівців, їх рефлексію та готовність до застосування у практичній діяльності професійних умінь і навичок [6]. У цьому контексті великого значення у процесі професійної підготовки майбутніх фахівців, зокрема у галузі стоматології, набуває необхід- 
ність формування іншомовної компетентності (IK), яка сприятиме ефективному здійсненню лікарської і дослідницької діяльності [3]. Процес формування IK майбутніх стоматологів вимагає використання різних інноваційних технологій в освітньому процесі (рольові ігри, дискусії, дебати, творчі проекти та ін.) [10]. На практичних заняттях з іноземної мови у медичних закладах вищої освіти, де студенти опановують іноземну мову за професійним спрямуванням, не менш важливим завданням $€$ опанування професійно-спрямованої лексики, що пов'язана $з$ людською діяльністю і стосунками у процесі виконання професійних обов'язків [2]. Для вирішення цього завдання великого значення набуває використання автентичних матеріалів. Основним джерелом автентичної іноземної мови $\epsilon$ відеоматеріали, що можуть бути використані на заняттях з іноземної мови як засіб формування іншомовної компетентності майбутніх фахівців із стоматології. Відеоматеріалом є будь-який матеріал (відеофільм, відеофрагмент, відеокурс, відеопрограма), що підлягає демонстрації в навчальних цілях з використанням відеотехніки [2]. Особливості використання відеоматеріалів на занятті з іноземної мови були досліджені такими зарубіжними науковцями, як Дж. Хармер [8, 9], Дж. Скрівенер [11] тощо. Аналіз вітчизняних наукових джерел $[1,4]$ дає підстави стверджувати, що більшість викладачів не приділяє достатньої уваги використанню відеоматеріалів на занятті 3 іноземної мови. Методика роботи з відеоматеріалом часто зводиться до звичайного перегляду відео і виконання вправ на переказ або написання твору [4]. Як наслідок, поставлена мета - формування іншомовної компетентності майбутнього фахівця - не досягається повною мірою. Таким чином, для підвищення ефективності процесу формування IK, використання відеоматеріалів на занятті з іноземної мови вимагає чіткої організації роботи.

Мета статті - проаналізувати переваги використання відеоматеріалів, як засобу формування іншомовної компетентності майбутніх фахівців із стоматології, та визначити основні етапи роботи 3 ними на заняттях з іноземної мови.

Теоретична частина. Відеоматеріал $€$ засобом формування IK, що обумовлюється високою ефективністю дії наочних образів. Інформація, представлена в наочній формі, є найбільш доступною для сприйняття, засвоюється швидше і якісніше. Використання відеоматеріалів на заняттях допомагає задовольнити інтереси студентів та має багато переваг як для викладача, так і для студентів [2]. Зокрема, у медичних 3ВО, де викладач іноземної мови не $є$ фахівцем у професійному аспекті, що вивчається студентами, відеоматеріали, підготовлені спеціально для навчальних цілей носіями мови та експертами в професійній тематиці, є дуже корисними [2]. Використання відеоматеріалів як засобу формування IK майбутніх фахівців із стоматології дозволяє вирішувати важливі завдання.

По-перше, при перегляді відеоматеріалів, більшість 3 яких видано носіями мови 3 навчальною метою, студенти мають можливість чути автентичну англійську мову, що сприяє кращому формуванню фонетичної складової ІК майбутніх стоматологів [3].

По-друге, відеоматеріали наочно зображують теоретичну інформацію, яка подана у підручнику або пояснюється на занятті. Переглядаючи відеоматеріали студенти-стоматологи дізнаються більше фахової інформації про анатомічну будову людини, фізіологічні, патологічні процеси та методи лікування хвороб. Використання відеопідтримки на заняттях сприяє підвищенню якості формування IK майбутніх стоматологів, оскільки дозволяє використовувати всі можливі види комунікативної діяльності: аудіювання, мовлення, читання і письмо. Використання відеоматеріалів залишається актуальним, оскільки саме через органи зору і слуху людина отримує основний об'єм інформації про навколишній світ. Зазначимо, що одна з обов'язкових умов ефективного формування IK є висока мотивація студентів, над підвищенням якої слід працювати постійно, а залучення відеоматеріалів до освітнього процесу сприяє успішному вирішенню цього завдання [2]. Крім того, відеоматеріали - це засіб, який дає змогу збагатити словниковий запас студентів, а також $є$ способом формування іншомовної комунікативної компетентності як складової ІК майбутнього фахівця із стоматології [3, 7]. Таким чином, використання відеоматеріалів на заняттях з іноземної мови у медичних ЗВО сприяє розвитку мотивованості мовленнєвої діяльності та самомотивації студентів, за умов, коли відео викликає інтерес і зацікавленість у студента. Отже, викладачу необхідно прагнути того, щоб студенти були зацікавлені відеоматеріалами саме через розуміння мови, а не лише через цікавий сюжет. Ще однією перевагою використання відеоматеріалів на занятті є сила враження і емоційної дії його на студентів. Тому головна увага має бути спрямована на формування студентами особистої думки 3 
приводу побаченого. Успішне досягнення зазначеної мети можливе лише за умови методично організованої демонстрації та систематичного показу відеоматеріалів.

Відповідно до викладеного вище, демонстрація відеоматеріалу вимагає дотримання ряду умов, а саме відеоматеріал має:

- бути змістовним;

- бути точно узгодженим з навчальним матеріалом;

- відповідати рівню знань студентів;

- бути не тривалим за часом;

- відповідати стандартам якості зображення та звуку.

Презентація відеоматеріалу, як засобу формування IK майбутніх фахівців із стоматології, може здійснюватися на різних етапах практичного заняття:

- перевірки домашнього завдання;

- пояснення нового матеріалу;

- закріплення вивченого матеріалу;

- перевірки знань у процесі заняття.

Презентацію відеоматеріалу доцільно проводити у чотири етапи: «підготовка», «етап перегляду», «робота з відеоматеріалом» та «етап використання відеоматеріалу в комунікативній ситуації».

Перший етап «підготовка» спрямований на мотивування студентів та зняття можливих лексичних, граматичних або професійного характеру труднощів у сприйнятті відео. На цьому етапі доцільне використання таких типів завдань:

- передбачення лексичних одиниць, що наявні у відеоматеріалі;

- поєднання лексичних одиниць, що наявні у відеоматеріалі, з відповідним перекладом на рідну мову;

- поєднання лексичних одиниць, що наявні у відеоматеріалі, з малюнком або фотографією.

Наступний «етап перегляду» спрямований на забезпечення подальшого розвитку іншомовної компетентності студентів-стоматологів з урахуванням їх реальних можливостей іншомовного спілкування. Цей етап передбачає фактичну демонстрацію відеоматеріалу.

На даному етапі відеоматеріал доцільно переглянути декілька разів, але кожна демонстрація відеоматеріалу студентам повинна відповідати певній меті. Існує два види перегляду відеоматеріалів: на виокремлення головної інформації та на виокремлення детальної інформації [10, 11]. Відповідно до мети перегляду відеоматеріалів, визначається добір вправ та завдань.
Типи вправ, що можуть бути використані на пошук головної інформації, містять завдання:

- назвати тему відео;

- обрати найбільш відповідний варіант назви представленого до перегляду відео;

- запропонувати власну назву відеоматеріалу.

Типи завдань, що можуть бути використані на виокремлення детальної інформації, такі:

- написання пропущеної інформації під час перегляду відеофрагмента;

- написання субтитрів до відео;

- перегляд відео без звуку: студенти обговорюють побачене, і припускають, що дійові особи говорять насправді;

- прослуховування відео без зображення: це змінює попередню процедуру на прямо протилежну. Поки студенти прослуховують відеоматеріал, вони намагаються уявити, де відбувається дія та що трапляється з дійовими особами;

- пошук правильних відповідей на питання;

- визначення правильних/неправильних стверджень; поєднання частин стверджень, що мають однакове змістовне навантаження;

- вибудовування логічної послідовності з окремих частин тексту;

- ставлення питань до побаченого;

- встановлення причинно-наслідкових зв'язків;

- перегляд відео у підгрупах: перша підгрупа сидить обличчям до екрана, друга підгрупа - спиною до нього, після чого підгрупи обмінюються інформацією;

- перегляд студентами різних частин одного відеофрагмента та обговорення цих частин з метою отримання повної інформації про відеофрагмент.

Етап «робота з відеоматеріалом» спрямований на використання початкового тексту як основи й опори для формування іншомовної комунікативної компетентності [2]. Для досягнення мети зазначеного етапу доцільно використовувати завдання, що стосуються:

- обговорення змісту відеофрагмента в цілому;

- рольові ігри, в основу яких покладений сюжет або ситуації відеофрагмента;

- дискусії щодо змісту відео;

- написання власного варіанта завершення відео;

- написання статті або рецензії щодо побаченого.

Основу роботи, під час виконання зазначених завдань, становить коментування, обговорення, інтерпретація розглянутих у відеоматеріалі проблем без опори на вербальні стимули [2]. 
Додатковим етапом роботи з відеоматеріалом $€$ етап «використання відео в комунікативній ситуації», коли студенти використовують зміст побаченого, у представленому відеоматеріалі, для вирішення інших комунікативних завдань. Таким чином, зміст відеоматеріалу стосовно певного стоматологічного захворювання студенти можуть використати для виконання комунікативних завдань щодо його ускладнення. Наприклад, відеоматеріал щодо видалення зубів доцільно використати для обговорення таких ускладнень, як кровотеча, травми темпоромандибулярного суглоба або пошкодження нерва. Відповідно, на цьому етапі доцільним є використання таких завдань, як:

- проектна робота;

- інтерв'ю;

- «круглі столи»;

- дебати, де студенти аргументують власну точку зору.

Отже, зазначене вище дає підстави стверджувати, що відеоматеріал - це ефективний засіб формування ІК майбутніх фахівців із стоматології, оскільки

\section{Список літератури}

1. Гальскова Н. Д. Современная методика обучения иностранным языкам / Н. Д. Гальскова. - М. : Глосса, 2000.

2. Захарова В. О. Особливості використання відеоматеріалів на заняттях з іноземної мови у вищих навчальних закладах / В. О. Захарова // Науковий вісник Національного університету біоресурсів і природокористування України. Ч. 2. - К., 2015. - С. 81-88.

3. Кульбашна Я. А. Структура іншомовної компетентності майбутніх фахівців із стоматології / Я. А. Кульбашна, В. О. Захарова // Освітологія. - 2018. - № 7. C. 157-163.

4. Мостєпан Н. М. Демонстрація відео на уроках: методичний аспект / Н. М. Мостєпан. - Кривий Ріг, 2012. -23 с.

5. Нагач М. В. Підготовка майбутніх учителів у школах професійного розвитку в США : автореф. дис. на здобуття наук. ступеня канд. пед. наук / М. В. Нагач. - К., 2008. - 21 c.

6. Новітні впровадження в педагогічний процес викладання радіології на третьому курсі медичного факультету / I. М. Леськів, І. В. Жулкевич, І. Й. Галайчук,

\section{References}

1. Galskova, N.D. (2000). Sovremennaya metodika obucheniya inostrannym yazykam [Modern methodology of teaching foreign languages]. Moscow: Glossa [in Russian]. він активізує увагу студентів та, водночас, сприяє вдосконаленню їх навичок аудіювання та мовлення. Окрім змістовної сторони спілкування, відеоматеріал містить візуальну інформацію про місце події, зовнішній вигляд і невербальну поведінку учасників спілкування в конкретній ситуації. Відео може мати сильний емоційний вплив на студентів, перетворюючись на стимул для додаткової мотивації у подальшому професійному розвитку.

Висновки та перспективи подальших досліджень. У статті проаналізовані переваги використання відеоматеріалів, як засобу формування іншомовної компетентності майбутніх фахівців із стоматології, та визначені етапи його презентації (етап «підготовки», «етап перегляду», «робота 3 відеоматеріалом» та етап «використання відео в комунікативних ситуаціях») на практичних заняттях 3 іноземної мови у медичних закладах вищої освіти.

Перспективи подальших наукових досліджень полягають у розробці методики формування іншомовної компетентності майбутніх фахівців із стоматології засобом автентичного тексту.

Н. О. Загурська // Медична освіта. - 2014. - № 1. - С. 64 66. - Режим доступу : https://ojs.tdmu.edu.ua/index.php/ med_osvita/article/view/3724.

7. Рудницька К. В. Сутність понять «компетентнісний підхід», «компетентність», «компетенція», «професійна компетентність» у світлі сучасної освітньої парадигми / К. В. Рудницька // Науковий вісник Ужгородського національного університету. Серія : Педагогіка. Соціальна робота. - 2016. - Вип. 1. - С. 241-244. - URL : http:// nbuv.gov.ua/UJRN/Nvuuped_2016_1_61.

8. Harmer J. How to teach English / J. Harmer. - L. : Longman, 2000. - 198 p.

9. Harmer J. The practice of English language teaching / J. Harmer. - London: Longman Group UK Limited, 1991. $371 \mathrm{p}$.

10. Kulbashna Ya. Future doctors’ professional competence formation in medical universities with innovative pedagogical technologies / Ya. Kulbashna, I. Skrypnyk, V. Zakharova // Open Journal of Social Sciences. - 2019. No. 7. - P. 231-242.

11. Scrivener J. Learning Teaching / J. Scrivener. London : Collins ELT, 2002. - 432 p.

2. Zakharova, V.O. (2015). Osoblyvosti vykorystannia videomaterialiv na zaniattiakh z inozemnoi movy u vyshchykh navchalnykh zakladakh [The peculiarities of using video in 
the foreign language classes at higher educational establishments]. Naukovyi visnyk Natsionalnoho universytetu bioresursiv i pryrodokorystuvannia Ukrainy - Scientific Bulletin of the National University of Life and Environmental Sciences of Ukraine, 2, 81-88 [in Ukrainian].

3. Kulbashna, Ya.A., \& Zakharova, V.O. (2018). Struktura inshomovnoi kompetentnosti maibutnikh fakhivtsiv iz stomatolohii [The structure of future dentists' foreign language competence]. Osvitolohiia - Education, 7, 157-163 [in Ukrainian].

4. Mostiepan, N.M. (2012). Demonstratsiia video na urokakh: metodychnyi aspect [Presenting video during the lessons: methodological aspect]. Kryvyi Rih [in Ukrainian].

5. Nahach, M.V. (2008). Pidhotovka maibutnikh uchyteliv u shkolakh profesiinoho rozvytku v SShA [Training of future teachers at schools of professional development in the USA]. Extended abstract of Candidate's thesis: "Teoriia i metodyka profesiinoi osvity”. Kyiv: Universytet menedzhmentu osvity Akademii pedahohichnykh nauk Ukrainy [in Ukrainian].

6. Leskiv, I.M., Zhulkevych, I.V., Halaichuk, I.Y., \& Zahurska, N.O. (2014). Newest introduction into educational process of teaching radiology on 3-rd course of the medical faculty. Medychna osvita - Medical Education, 1, 64-66. Retrieved from: https://ojs.tdmu.edu.ua/index.php/med_ osvita/article/view/3724
7. Rudnytska, K.V. (2016). Sutnist poniat "kompetentnisnyi pidkhid”, “kompetentnist”, “kompetensiia”, “profesiina kompetentnist” u svitli suchasnoi osvitnoi paradyhmy" [Meaning of notions "competency-based approach", “competency”, “competence”, "professional competence” in terms of modern educational paradigm [The essence of the concepts "competence approach”, “competence”, “competence”, "professional competence” in the light of the modern educational paradigm]. Naukovyi visnyk Uzhhorodskoho natsionalnoho universytetu. Seriia: Pedahohika. Sotsialna robota - Scientific Bulletin of Uzhhorod National University. Series: Pedagogy. Social work, 1, 241-244. Retrieved from: http://nbuv.gov.ua/UJRN/Nvuuped_2016_1_61 [in Ukrainian].

8. Harmer, J. (2001). How to teach English. London: Longman.

9. Harmer, J. (1991). The practice of English language teaching. London: Longman Group UK Limited.

10. Kulbashna, Ya., Skrypnyk, I., \& Zakharova, V. (2019). Future doctors professional competence formation in medical universities with innovative pedagogical technologies. Open Journal of Social Sciences, 7, 231-242.

11. Scrivener, J. (2002). Learning teaching. London: Collins ELT.

Електронна адреса для листування: valerieozakharova@gmail.com 